\title{
Data Management of Indonesian Warship's Electronic Support Measures in Supporting Naval Operation
}

\author{
Bekti Sutiarso \\ Magister of Naval Operations Study Program, Indonesian Naval Command and Staff College \\ Ciledug Raya Street Number 2 \\ Cipulir, Kebayoran Lama, South Jakarta, DKI Jakarta 12230, Indonesia
}

\begin{abstract}
The development of science and technology is very influential in all fields of life, including the military sector. This encourages countries throughout the world competing to compete in the sophistication of military defense equipment. Competition in the military field has the potential for a new style of warfare so there was a new threat. One such threat is Electronic Warfare, this is a war model in the era of modern technology. Electronic Support Measure is part of the Electronic Warfare that is passive, but very decisive in excellence in battle. Data of Electronic Support Measure processed in a Big Data that can be used in Indonesian Naval Operation. For this reason, a good Electronic Support Measure Intercept Data Management is needed in the context of readiness of Indonesian fleet command in naval operation.
\end{abstract}

Keywords: Data Management; Electronic Support Measure (ESM); Naval Operation; Electronic Warfare (EW), Big Data.

DOI: $10.7176 / \mathrm{IKM} / 10-1-03$

Publication date: January $31^{\text {st }} 2020$

\section{INTRODUCTION}

Indonesian Navy is a component of the state defense system which holds the Indonesia Armed Forces duties in the field of defence and enforcing the law and maintains security in the maritime region of the national jurisdiction in accordance with national and legal provisions International has been ratified (Laws Nb. 34, 2004). One of the Indonesian Navy's duties in accordance with the task in the Military Operations of War is the naval operations that is a series of Sea Battle conducted by a unit of fleet independently or in combination/cooperation with other forces in a particular area and within a certain period of time and bound by one purpose and one plan and directed towards achieving strategic objectives, tactics, logistics and training (Seskoal, 2019).

The excellence in naval operations was heavily influenced by the reliability of the Indonesian warship in carrying out of sea battle. Electronic warfare is a part of the general warfare, the main of the operation of electronic warfare is its ability to prevent and reduce effectiveness of the use of electromagnetic waves by opponents and ensure the effectiveness of the use of electromagnetic waves by its own unity (Seskoal, 1995). Excellence in control of the electromagnetic wave spectrum greatly determines the success in maritime operations implementation.

Capability and equipment of electronic warfare that is owned by Indonesian Warships especially in the current combatants ships one of which is the ESM in the operational displaced to search, intercept, identify, locate and report the source of electromagnetic wave radiation of the parties opponent.

The data management of ESM is indispensable in the implementation of electronic warfare. The ESM consciousness data was obtained from the results of the Indonesian Warships operations implemented. The data and renewal of a lead augmented ESM is part of the data management of the ESM lead augmented, on the basis that researchers conduct research to find out how the result data management of the ESM to support the implementation of naval operations. (Seskoal, 1995)

Researchers carry out research on the management of the data of the ESM Indonesian Warships to the implementation of maritime operations with the aim of naval operations.

\section{OUTLINE THEORY}

\subsection{Theory Description}

\subsubsection{Data Management}

Data management is a form of information resource management activities that include, first the process of collecting data and recording into documents that serve as input for the system. Secondly, the process of storing resource information into a document file. Thirdly, maintenance of the process of adding new data and changes in existing data so that information resources remain update. Fourth, organize the process of drafting the data in such a way as to meet the needs of the users information (Jogiyanto, 2005).

\subsubsection{Electronic Warfare}

Electronic warfare is a military operation activity involving the use of electromagnetic wave energy with the aim of search, intercept, identify, determining, reducing and preventing opponents from using the wave spectrum 
Electromagnetic and ensure the effectiveness of the use of its own electromagnetic wave spectrum (Seskoal, 1995)

\subsubsection{Naval Operation}

The purpose of naval operations is to enforce the sovereignty of the State at sea, to prevent/defend, and to crack down on all forms of military and non-military threats conducted in or through the sea, ensuring the implementation of naval control for the benefit of sea control, preventing and hindering the use of the seas by the sea denial, and the creation of law and sovereignty in the sea to be safe and free from threats or disruption to the activities of use/utilization of the sea (TNI AL, 2008)

\subsubsection{Sea Power}

Naval strategy has for its end to found, support, and increase, as well in peace as in war, the sea power of a country (Mahan, 1890). Based on the above theory, it is necessary to have a tangible presence in the efforts of naval control carried out by the Indonesian Navy which was realized in operation of the sea to secure the interests of the country at sea.

\subsubsection{The Art of Warfare}

Sun Tzu mentions if we can make an enemy show its position while covering our position from it, we will be fully empowered while he is divided (Ames, 2002). Based on Sun Tzu's theory, it is crucial that there is an effort to know the position and direction of the threat, in the context of modern warfare, the advantage of information about enemy forces and sea battle territory from the data analysis of the Electronic Counter Measure Warship.

\section{METHODOLOGY}

\subsection{Research methods}

The research methods used in this study are quantitative. This method is called quantitative method because of research data in the form of numbers and analysis using statistics. Quantitative methods can be interpreted as a research method based on the philosophy of positivism, used to research on certain populations or samples, data collection using research instruments, data analysis that is Quantitative/Statistically, with the aim to test the predetermined hypothesis (Sugiyono, 2013). Researchers conducted research with the dissemination of questionnaires to respondents to Indonesian warships officers who were not in operation. The data collection process is performed 23 May until 24 May 2019.

\subsection{Population and samples}

The population that was targeted for research was the officers who were directly related to the management Data of ESM Indonesian warships lead augmented as many as 57 officers. Using the formula of Slovin (Neolaka, 2014), samples were obtained by 36 officers who were responsible for the Data management of ESM Indonesian Warships.

\subsection{Data Collection and processing}

The Data on this research was obtained by distributing questionnaire/questionnaire against Indonesian Warships personnel who have ESM. After implemented editing, encoding and tabulation then the data is processed with statistical techniques using SPSS 25 for Windows program.

\subsection{Data Analysis Techniques}

\subsubsection{Validity tests}

The validity test is done by comparing the calculated $\mathrm{R}$ value by the $\mathrm{R}$ table to a significance level of 5 percent of the degree of freedom (DF) $=\mathrm{n}-2$, in this case $\mathrm{n}$ is the number of samples. When $\mathrm{r}$ calculate $>\mathrm{R}$ table then the question or indicator is valid, as well as vice versa when $r$ counts $<\mathrm{R}$ table then the question or indicator is declared invalid (Sugiyono, 2012)

\subsubsection{Reliability Test}

Reliability test is used to determine the extent to which the measurement results remain consistent, when performed twice or more measurements of the same symptoms using the same measuring instrument (Siregar, 2014). If the value of the Cronbach Alpha is greater than 0.60 then the overall statement is determined to be reliable.

\subsubsection{Normality Test}

Test normality is intended to know the data obtained by normal distribution or not. Data normality testing can be implemented using the Kolmogorov-Smimorv test based on the significant value of $>0.05$ then the normal distribution, and if it is significant $<0.05$ then the data is not a normal distribution (Siregar, 2014).

\subsubsection{Multiple linear regression analyses}

Multiple linear regression is used to determine the influence of one or more free variables. The implementation uses test- $T$ to determine whether there is partial influence between the free variables and the bound variables and the F-test to determine if the free variables in its entirety are statistically significant against variables are bound. 
(Riduwan, 2014).

\section{RESULTS AND DISCUSSION}

4.1 Data Management for the ESM Indonesian Warships's impact on naval operations

Calculation of $\mathrm{F}$ value gained from simple regression results of lead data management against sea operations

Table 1. Simultaneous multiple regression test results

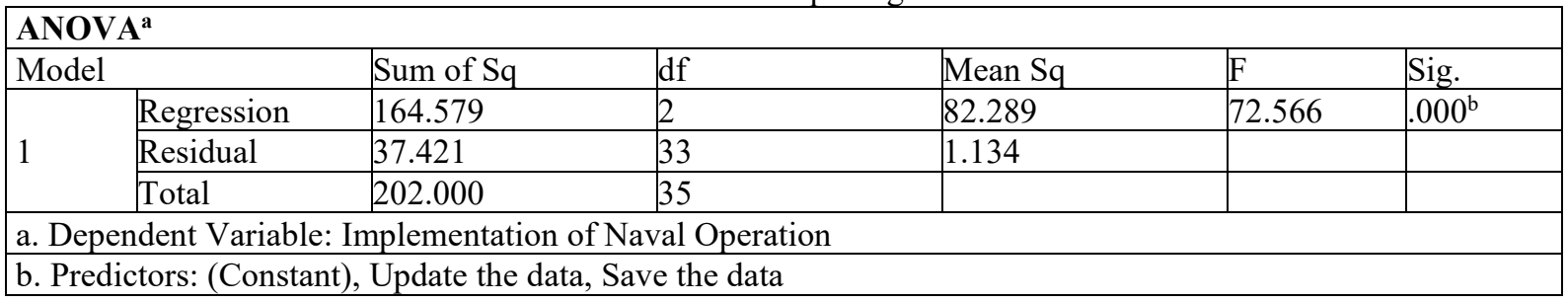

Source: Processed by researchers with SPSS 25

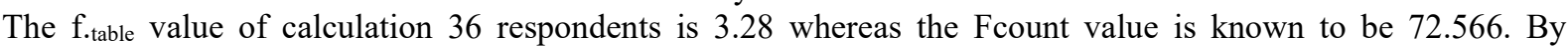
comparing the $\mathrm{F}$ count with $\mathrm{F}$ table retrieved $\mathrm{F}$.count $>\mathrm{F}_{\text {.table }}=72,566>3.28$. The significance value of the research calculated result of the realized data retention variable is 0.000 and when compared to $\alpha$ value $=0.05$ so that the value of the research result is less than the probability.

Table 2. Data Augmented retention regression coefficient and update of Data Augmented

\begin{tabular}{|c|c|c|c|c|c|c|}
\hline \multicolumn{7}{|c|}{ Coefficients $^{\mathbf{a}}$} \\
\hline \multirow{2}{*}{\multicolumn{2}{|c|}{ Model }} & Unstd Coeff. & & Std.Coeff. & \multirow{2}{*}{$\mathrm{t}$} & \multirow{2}{*}{ Sig. } \\
\hline & & $\mathrm{B}$ & Std. Error & Beta & & \\
\hline \multirow{3}{*}{1} & (Constant) & .582 & 2.898 & & .201 & .842 \\
\hline & Storage & .437 & .092 & .955 & 4.740 & .000 \\
\hline & Update & -.032 & .116 & -.056 & -.279 & .782 \\
\hline
\end{tabular}

a. Dependent Variable: Naval Operation Implementation

Source: Processed by researchers with SPSS 25

Based on table above obtained regression equation: storage

$\mathbf{Y}=\mathbf{a}+\mathbf{b} 1(\mathbf{X} 1)+\mathbf{b 2}(\mathbf{X} 2)$

$\mathrm{Y}=\mathbf{0 , 5 8 2}+\mathbf{0 , 4 3 7}(\mathrm{X} 1)-\mathbf{0 , 3 2}(\mathrm{X} 2)$

From the results of the regression equation then the researcher can explain as follows:

a. $\alpha=0.582$, meaning when save the data variable is realized (X1) and the update the data is equal to zero, the Naval operations implemented increased by 0.582 points.

b. $b 1=0.437$, meaning variable regression coefficient of consciousness save the data (X1) by 0.437 and be interpreted in case of changes save the data retention will affect the implementation of naval operations by 0.437 assuming the update the data variable Constant data (X2).

c. b2 $=-0.032$ means variable regression coefficient updates the data (X2) by-0.032 and can be interpreted in case of update changes in the lead data will affect the implementation of sea operations by- 0.032 assuming save the data variables (X1) constant.

Results of calculation of the coefficient of save the data and update the data to the implementation of naval operations can be seen in table 3 below:

Table 3. Coefficient of simultaneous determination

\begin{tabular}{|l|l|l|l|l|}
\hline \multicolumn{4}{|c|}{ Model Summary } \\
\hline Model & $\mathrm{R}$ & $\mathrm{R} \mathrm{Sq}$ & Adj R Sq & Std. Error Estimate \\
\hline 1 & $.903 \mathrm{a}$ & .815 & .804 & 106.489 \\
\hline a. Predictors: (Constant), Update the data, Save the data \\
\hline
\end{tabular}

Source: Processed by researchers with SPSS 25

Based on the table above the value of coefficient of determination (R Square) of 0.903 , it can be concluded that save the data and update the data can affect the operation of sea operations by $90.3 \%$.

Based on the results of the calculation using SPSS 25 for windows to knowing the effect of simultaneous inependent variables on the dependent variables can be concluded there are significant simultaneous links between save the data and update the data to the implementation of Naval operations with an F.count proof count greater than the $F_{\text {.table }}$ and the calculated sig value below 0.05 .

\section{Conclusion}

Based on the research results that researchers have implemented and data processing using SPSS 25 for 
Windows then researchers can take conclusions against the ESM Data management in a good way that significantly affects and Positive value for naval operations implementation. These results indicate that the factors of the save the data and update of the data ESM will replenish each other and complement each other, or in other words both support the improvement of naval operation.

\section{References}

Ames, R. (2002). Sun Tzu The Art of Warfare. Batam: Lucky Publishers.

Jogiyanto, H. (2005). Analisa dan Desain Sistem Informasi: Pendekatan Terstruktur Teori dan Praktik Aplikasi Bisnis. Yogyakarta: ANDI.

Mahan, A.T. (1890). The Influence of Sea Power upon History. Boston: Little Brown and Company.

Neolaka, A. (2014). Metode Penelitian dan Statistik. BandungRemaja Rosdakarya.

Riduwan. (2014). Metode dan Teknik Menyusun Tesis. Bandung: Alfabeta.

Seskoal. (1995). Paket Instruksi Peperangan Elektronika. Jakarta: Seskoal.

Seskoal. (2019). Paket Instruksi Operasi Laut Gabungan. Jakarta: Seskoal.

Siregar, S. (2014). Statistik Parametrik Untuk Penelitian Kuantitatif. Jakarta: Bumi Aksara.

Sugiyono. (2012). Statistika Untuk Penelitian. Bandung: Alfabeta.

Sugiyono. (2013). Metode Penelitian Kombinasi (Mix Methods). Bandung: Alfabeta.

TNI. (2018). Doktrin Tri Dharma Eka Karma. Jakarta: TNI.

TNI AL. (2008). Buku Petunjuk Operasi TNI Tentang Operasi Laut. Jakarta: Seskoal.

UU No. 34. (2004). Tentara Nasional Indonesia. Jakarta. 